\section{Professional pride}

SIR - On page 542 of your issue of 18 February you inveigh against the "deceit" of groups of professional people who combine to campaign against nuclear weapons. On page 545 we read " . . . the Pentagon's Defense Science Board, chaired by Dr John Deutsch of the Massachusetts Institute of Technology, recommended a start on the production of binary weapons and that the Department of Defense should prepare for a major increase in its chemical warfare programmes". I do not recall having seen in your editorial columns any denunciation of this kind of professional activity. Apparently it is all right for groups of bought scientists, operating mainly in secret, to promote the development of the instruments of mass murder, but somehow deceitful for groups of free scientists, meeting in public, to take the contrary stance.

J.R.S. FINCHAM

Department of Genetics,

University of Edinburgh,

Edinburgh, UK

\section{Protein evolution}

SIR - Hoyle and Wickramasinghe believe, probably correctly, that the age of the Earth is not great enough to have given time for chance mutations to produce enzymes specified at every point in a chain of, say, 200 amino acid units. Jukes (Nature 18 February 1982, p.548) replies that proteins evolve by elongation of small polypeptides. This reply is insufficient if the elongation process must still produce a unique arrangement of amino acid units of the chain length of the final enzyme.

The size of the initial polypeptide is irrelevant. The essential point is (see also Nature 3 December 1981, p.396) that enzymatic activity of a particular kind can arise from quite short lengths of polypeptide chain, for example six amino acid units. The rest of the chain, if present, may gain significance in the course of evolution, and must certainly have the property of not folding so as to enclose the active part of the chain. The presence of life on this planet does not, however, depend, as Hoyle supposes, on the emergence of the complete chain, specified point by point. The minimal length required for a particular enzymatic activity would not require Hoyle's endless aeons to appear by chance; it would be already present in the primitive ocean.

A.E. Rout

British National Oil Corporation

(Trading) Ltd,

London WI, UK

\section{A wing and a prayer}

SIR - Is Jukes a secret believer, or merely an unwary fox in among the fundamentalist chickens? The ancestral relationship he implies between the biplane and the Boeing 747 (Nature 18 February, p.548) is one of design, not of descent. This is a striking counterpart of the creation process. Tragically, God's Concorde has fallen a long way since his maiden bite at the evolutionary tree, and even American jumbos finally land up in (we hope) US junkyards. Pigs might, but they have the good sense not to try.

C. DARNBROUGH

The University of Glasgow,

Glasgow, UK

\section{Electricity costs}

SIR - Professor Fremlin (Nature 1 October 1981, p.332) wonders why the retail price index is used to correct for inflation. The short answer is given by the Central Electricity Generating Board's (CEGB's) 1980-81 report, paragraph 168. "The cost per $\mathrm{kWh}$ of fuel . . rose by 18.6 per cent (between $1979-80$ and 1980-81). This was higher than the general inflation rate (a 16.3 per cent increase in the RPI) for a number of reasons". RPI is used almost universally as a measure of the general inflation rate. It also favours nuclear costs.

I have previously dealt ${ }^{1}$ fully with the question of interest rates for comparison purposes, and if Professor Fremlin wants to discover an investment giving a steady 5 per cent above inflation rate I suggest he keeps an eye on his electricity bills, because they will have to cover a real 5 per cent interest on the funds being built up for decommissioning etc., by CEGB.

As far as accuracy is concerned, CEGB cost figures are given to 1 in 10,000 , so my 1 per cent accuracy in the tables of my letter (see Nature 27 August 1981, p.791) hardly requires a probable error. Where "estimated minimum (or probable) corrections"' are given, the "error" arises from the refusal to release available accurate information and its magnitude is known only to CEGB.

On future action, until Professor Fremlin is prepared to take real account of the work of Gerald Leach and his colleagues ${ }^{2}$, I cannot take seriously such ex cathedra statements as his last sentence, "As of now it (nuclear power) is the only means capable of the scale of output needed".

I accept that cost ratios in 25 years' time are far more uncertain that the differences between my figures and those of CEGB. (Although it seems that there is considerably more uncertainty on nuclear than on coal costs.) The importance of the calculations of present costs is that CEGB claimed to be able to produce cheaper electricity by building new nuclear power stations immediately (Heysham II and the Sizewell PWR) even though they were not needed to satisfy demand. It has now been demonstrated ${ }^{1}$ that this claim was entirely dependent on the assumption of a massive ( 36 per cent) increase in the real cost of coal to CEGB over the six years of the construction period (1980-86). This assumption was very effectively camouflaged in the board's documents and this is not surprising since it was made at almost exactly the same time as the "understanding" was entered into with the National Coal Board which practically guarantees that the real cost of coal to CEGB will not rise at all between 1980 and 1985.

In that case building Heysham II will certainly result in dearer electricity than if it had not been built, but instead the large overcapacity of coal-fired stations, which are at present being prematurely retired, had continued in operation.

Building unnecessary expensive new power stations may not bankrupt CEGB, but it will not help industry get cheaper electricity.

J.W. JEFFERY

Birkbeck College,

University of London, $U K$

Jeffery, J.W. Energy Policy 10, No. 2 (in the press). 2. Leach, G. et al. IIED Sci. Rev. (1979).

\section{PCBs in rice oil}

SIR - In March 1979, patients suffering from chloracne began appearing on the west coast of Taiwan. By October the disease had reached epidemic proportions, affecting over 1,100 people in the T'aichung and Changhua prefectures.

The exposure factor common to these patients was the consumption of rice oil produced by the same rice oil processing company situated in Changhua prefecture. Investigation of the manufacturing process identified a leak in a heat exchanger, which resulted in oil contamination with Kanechlor 400 , a 48 per cent chlorinated biphenyl. In addition to symptoms associated with chloracne, clinical signs included respiratory symptoms, decrease in conduction velocity in peripheral sensory nerves, diminished growth in young children, and four reported cases of pigmented skin in newborns, all of whom died within a year of birth.

The same type of mass rice oil contamination was reported in western Japan in $1968^{1}$, affecting more than one thousand victims. These were cases of direct consumption of high doses of polychlorinated biphenyls. The use of these substances was banned in Taiwan in 1972, but that did not prevent this recurrence, which is evidence that Kanechlor 400 is still being used in the heat exchange process during the production of oil for human consumption. This recurrence should serve as a warning to those Asiatic riceproducing countries which still use these oil production systems.

University of Michigan,

William Y.B. Chang Ann Arbor, Michigan, USA

1. World Health Organization Envir. Hlth Criteria 2 (1976).

\section{Holmes' lives on}

SIR - What's this nonsense about Holmes' Principles of Physical Geology being "long out of print"? ("What Makes a Good Textbook"; Nature 11 February, p.459.) This work has never been out of print. A comprehensively revised third edition was prepared by Sir Arthur's widow Doris (herself a fine geologist in her own right) and published in a revised format in 1978. The book has, as you say, been a great success both critically and commercially. It continues to be so after nearly 40 years of uninterrupted availability. DOMINIC RECALDIN Thomas Nelson \& Sons Ltd, Walton-on-Thames, Surrey, UK

\section{An end to creation?}

SIR - Why do you continue to publish letters on creationism? I am reasonably confident that you would not publish arguments on whether the Earth is flat or whether epilepsy is caused by demoniacal possession.

Of course, scientists are entitled to their private superstitions; but they have no place in a supposedly serious journal. Pray let us see those long overdue words: "This correspondence is now closed."

M. HAMMERTON

Department of Psychology,

University of Newcastle upon Tyne, UK 